\title{
Research on Three-dimensional Teaching Practice Pattern of Human Resource Management in Colleges
}

\author{
Aijuan Chen \\ Hanshan Normal University \\ Chaozhou, China
}

\begin{abstract}
According to the analysis of teaching status of human resource management in colleges at home and abroad, major problems are found, meanwhile, the three-dimensional teaching practice pattern of human resource management in colleges is researched through building six function modules of human resources, formulating schedule of practical teaching and building professional laboratories.
\end{abstract}

Keywords-human resource management; practical teaching; three-dimensional

\section{INTRODUCTION}

In recent years, enterprises need more and more human resource management personnel. Colleges attach increasing importance to practical teaching in training students major in human resource management. The construction of threedimensional teaching platform of human resource management plays a key role in deepening students' understanding of theoretical knowledge and training their ability of practical operation in work.

\section{ANALYSIS ON TEACHING StATUS OF HUMAN RESOURCE MANAGEMENT IN COLLEGES AT HOME AND ABROAD}

In recent years, the practical teaching of human resource management major at home and abroad gets unprecedented development.

As for the time arrangement of practical teaching, in American higher education, practical courses account for 75 percent of all the courses. The time of social practice is 600 to 1,300 hours. Practical teaching in Britain accounts for 65 percent of the total teaching hours. [1] The undergraduate courses of organization and management department in Marshall School of Business in University of Southern California emphasize the functions of human resource management. Students are provided with many practical courses. [2]

With regard to the contents of practical teaching, the practical teaching of human resource management in America values personnel assessment, negotiation techniques, salary administration, employee motivation and decision based on data. [3] Simulation drilling and practice are provided for key

Project source: Guangdong province innovative school project "Research on Establishment of Platform of Three-dimensional Teaching Application Practice in Human Resource Management" (Approval number: Guangdong Jiao Gao Han [2016] No. 236) links. Teaching forms are diversified such as lecture course, discussion course, remedial lesson, laboratory course, case study, situational simulation, project study and role play. Students' team-work spirit, innovation consciousness and manipulative ability can be strengthened through studentoriented scientific research activities, teachers' patient guidance and close cooperation between students. Modern teaching tools like VCR, sound recorder and projector as well as telecommunications network are widely used by teachers. In Britain, teaching forms are very popular. Students major in human resource management can obtain more practice posts and opportunities. [4]

\section{ANALYSIS ON TEACHING STATUS OF HUMAN RESOURCE MANAGEMENT IN DOMESTIC COLLEGES}

At present, the construction of human resource management major has entered the period of organized conscious development. Researches in practical teaching are developing in diversified ways. The existing researches of domestic scholars focus on the practical teaching pattern, the formation of practical teaching system, practical teaching methods and construction of practice platforms in the human resource management major.

As for the practical teaching pattern, Wang Mingqin proposes it includes experiment teaching, case teaching, practical activity, academic report and social investigations in holiday. [5]

As for the formation of practical teaching system, Chen Jinkun and Sun Zhengguo propose the integral practical teaching system includes forms, places and time of practical teaching. It has many forms including course experiment, course teaching practice, professional practice, practical training and production practice, graduation design and social practice as well as consultation service. [6] Nan Zhizhen concludes the practice of practical teaching link in Shanxi Economic Management Cadre College, the demonstration pilot project of human resource management major, and thinks practical teaching is an integral system formed by cognition practice, course practice and comprehensive practice. The period of practical teaching accounts for 40 percent of the total class hour in this major. [7]

As for the practical teaching methods, after concluding the teaching experience, Wang Guijun thinks good teaching methods include case discussion and analysis, scenario 
demonstration and simulation, information retrieval, paper writing, social investigation, project design, video display, special lecture, online self-study, internet interaction, experience exchange with upperclassman, lessons taught by students, activities in human resource association, play activity, visit and inspection. Case discussion and analysis is the most frequently-used and easiest method in teaching because of its characteristics of user-friendly control, low cost, high degree of students' participation and good teaching effects. Furthermore, he addresses teachers can lead students to form groups on research topics, carry out social investigation and "the program under which officials, doctors, scientist and college students go to the countryside to spread scientific and literacy knowledge and offer medical service to farmers" in summer vacation. [8] In order to train college students' employment ability, Sa Rula suggests the provision of "practical classroom", including scenario simulation, group discussion, group extracurricular activities, have informal discussion with successful people and social practice. [9]

The research on the construction of practice platform is popular among experts and scholars at present as well as the highlight of human resource management research. Wang Guijun specifically analyzes the construction of training room and off-campus training base related to human resource management and proposes better effects will be achieved through building training base in personnel exchange center. [8] Chen Jinkun and Sun Zhengguo research the optimal deployment of practical teaching resources. [6] Since 2003, all previous China's Association of Human Resource Development Teaching and Practicing has paid high attention to researches on experiential teaching and the construction of practice base and specialized laboratories, and emphasizes it is urgent and necessary to strengthen practical education. Shanxi Economic Management Cadre College has constructed psychological skill labs, employee recruitment labs, brain lab, human resource practice room, workshop lab and simulation laboratory that simulates the human resource department of enterprises and has taken the lead in practical teaching.

\section{MAJOR PROBLEMS IN PRACTICAL TEACHING OF HUMAN RESOURCE MANAGEMENT IN COLLEGES}

Although college teachers in human resource management major have generally recognized the necessity of reforming the practical teaching system, breakthrough progress hasn't been made in theoretical discussion and practical application. From the perspective of the system integrity, the researches of existing literature are fragmented and local. Rare achievements have been made in practical teaching materials, practice and innovation as well as cooperation between industry, university and research related to the development of human resource management major. From the perspective of methodology, most literatures only have thinking and recapitulative and normative description and lack empirical researches and data support. From the perspective of applying value, most researches only conceive and urgently require the development of effective application methods and practical operation procedures. Therefore, we shoulder heavy responsibilities to explore the practical teaching system suitable for characteristics of human resource management and reality in our country.

\section{CONSTRUCt THREE-Dimensional TEACHING PATtERN of Human RESOURCE MANAGEMENT IN COLLEGES}

\section{A. Construct the practical teaching link based on six function modules}

Six function modules of human resource management include human resources strategic layout, employee recruitment and deployment, employee training and development, performance management, compensation and benefit and employee relationship management, covering almost all job contents of human resource management post and referring to the key points of theoretical teaching and difficulties of practical teaching.

In enterprise, on one hand, the work of the previous module is the foundation of the subsequent module. For example, the recruitment and deployment of employees bases on the forecast analysis on demand and supply of human resources in strategic planning. The training and development of employees base on the recruitment and deployment of employees. On the other hand, six modules are entirety with interrelation and harmonious development. Therefore, in the formulation of experiment teaching plan, the practical teaching of the six function modules cannot be independent but carry out coordinated development.

\section{B. Formulate Practical Teaching Schedule in the Whole Process}

In time design of practical teaching, refer to the practice of higher education in human resource management major in foreign countries and guarantee the class hour of practical teaching accounts for 50 to 65 percent of the total teaching hours. Make the best of lab resources and carry out practical teaching in winter and summer vacation in eight semesters from freshman to senior. Practical teaching in the whole process includes course experiment, simulation experiment, case teaching, social investigation, post practice and thesis. The practical teaching schedule in human resource management major can be formulated, as shown in "Table I". 
TABLE I. Practical Teaching Schedule IN The Whole Process

\begin{tabular}{|c|c|c|c|c|c|}
\hline No. & Experimental project & $\begin{array}{l}\text { Planned } \\
\text { period }\end{array}$ & $\begin{array}{l}\text { Number of } \\
\text { groups }\end{array}$ & $\begin{array}{l}\text { Number of people } \\
\text { in each group }\end{array}$ & Function module \\
\hline 1 & Position description compilation & 8 & 9 & 6 & \multirow{5}{*}{ Strategic planning } \\
\hline 2 & Work analysis group discussion & 6 & 9 & 6 & \\
\hline 3 & Human resource demand analysis & 6 & 9 & 6 & \\
\hline 4 & Human resource supply analysis & 6 & 9 & 6 & \\
\hline 5 & Personnel quality model construction & 10 & 9 & 6 & \\
\hline 6 & Recruitment demand analysis & 4 & 9 & 6 & \multirow{8}{*}{ Recruitment and deployment } \\
\hline 7 & Simulation recruitment & 8 & 9 & 6 & \\
\hline 8 & Structured interview & 10 & 9 & 6 & \\
\hline 9 & Role play & 10 & 9 & 6 & \\
\hline 10 & Leaderless group discussion & 10 & 9 & 6 & \\
\hline 11 & Hanaper test & 10 & 9 & 6 & \\
\hline 12 & Management game & 8 & 9 & 6 & \\
\hline 13 & Extempore speak & 4 & 9 & 6 & \\
\hline 14 & Training demand analysis & 6 & 9 & 6 & \\
\hline 15 & Training demand interview & 10 & 9 & 6 & Training and development \\
\hline 16 & Personnel training practice & 12 & 9 & 6 & \\
\hline 17 & Employee quality development & 12 & 9 & 6 & \\
\hline 18 & KPI application practice & 12 & 9 & 6 & \multirow{4}{*}{ Performance management } \\
\hline 19 & $360^{\circ}$ assessment simulation & 14 & 9 & 6 & \\
\hline 20 & Performance feedback interview & 8 & 9 & 6 & \\
\hline 21 & BSC application practice & 8 & 9 & 6 & \\
\hline 22 & Salary design analysis & 8 & 9 & 6 & \multirow{5}{*}{ Salary management } \\
\hline 23 & Salary interview & 12 & 9 & 6 & \\
\hline 24 & Salary and welfare calculation practice & 10 & 9 & 6 & \\
\hline 25 & Simulation of salary design & 12 & 9 & 6 & \\
\hline 26 & Salary case analysis & 14 & 9 & 6 & \\
\hline 27 & Case analysis in New Labor Law & 12 & 9 & 6 & \multirow{3}{*}{ Employee relation management } \\
\hline 28 & Simulation of labor dispute settlement & 16 & 9 & 6 & \\
\hline 29 & $\begin{array}{l}\text { Labor relations management in well-known } \\
\text { enterprises }\end{array}$ & 12 & 9 & 6 & \\
\hline 30 & ERP Sand Table Simulation & 14 & & 6 & Combined training \\
\hline 31 & Occupational image-building & 6 & 9 & 6 & \multirow{4}{*}{$\begin{array}{l}\text { First training in winter and summer } \\
\text { vacation }\end{array}$} \\
\hline 32 & Occupational quality experience & 12 & 9 & 6 & \\
\hline 33 & Professional quality expansion training & 12 & 9 & 6 & \\
\hline 34 & Post model cognition & 12 & 9 & 6 & \\
\hline 35 & Social investigation & 20 & 9 & 6 & $\begin{array}{l}\text { Second training in winter and summer } \\
\text { vacation }\end{array}$ \\
\hline 36 & Post practice & 20 & 9 & 6 & $\begin{array}{l}\text { Third training in winter and summer } \\
\text { vacation }\end{array}$ \\
\hline 37 & Thesis & 20 & 9 & 6 & $\begin{array}{l}\text { Fourth training in winter and summer } \\
\text { vacation }\end{array}$ \\
\hline
\end{tabular}

\section{Create Professional Practice Laboratory}

In order to train applied, compound and innovative talents, three-dimensional laboratory integrating elementary lab, professional characteristic laboratory and comprehensive research laboratory in human resource management major is created. The design of laboratory should fully integrate the existing experimental resources and meet the requirements of software at different levels. We should combine the advantages of traditional teaching pattern with modern teaching methods and carry out collaborative interaction of different experiments on the unified platform of the experimental center, in order to create a real and integral environment for human resource management in enterprises for students.

\section{CONCLUSION}

The education of human resource management major only has a history of about twenty years in our country and hasn't formed perfect teaching patterns and systems so far. The talent training pattern that values theory instead of practice has always been a defect in education of human resource management major. It is an effective method to build platform of three-dimensional teaching application practice in human resource management in order to train compound and applied talents required by enterprises and society.

\section{REFERENCES}

[1] Zeng Shuangquan. Curriculum Provision of American Teacher Education and Its Enlightenment on Our Country [J], Exam Weekly, 2009(2)

[2] Feng Weiming. Discussion on Innovation of Practical Teaching Pattern in Human Resource Management Major [J], Education of Science and Technology, 2009(2)

[3] Fan Guanhua. Practice and Enlightenment of Education in Human Resource Management in America-Based on the Perspective of 
Competency Development of Students [J], Comparative Education Review, 2012(9)

[4] Yang Xinrong. Build Practical Teaching System of Human Resource Management and Pay Attention to Practical Ability Training [J], Human Resource Management, 2008(11)

[5] Wang Mingqin. Construction of Module Course System in Human Resource Management Major [J], Heilongjiang Education, 2010(3)

[6] Chen Jinkun, Sun Zhengguo. Practical Teaching Resource Construction and Management Mechanism [J], China Agricultural Education, 2005(4)

[7] Nan Zhizhen. Exploration on Combination of Production and Study in Human Resource Management in Shanxi Economic Management Cadre College $[\mathrm{J}]$, Journal of Shanxi Economic Management Cadre College, 2005(09)

[8] Wang Guijun. Exploration on Manipulation Skill Training in Human Resource Management Major [J], Journal of Panyu Polytechnic, 2006(1)

[9] Sa Rula. Exploration on Diversified Comprehensive Teaching Model of Optional Course -Take the Course of "Human Resource Development and Management" as an Example [J], Ethnic Education Study, 2012(5) 